\title{
The care for institutionalized elderly perceived by the nursing team
}

\author{
O cuidar de pessoas idosas institucionalizadas \\ na percepção da equipe de enfermagem
}

El cuidado de ancianos institucionalizados

en la percepción del equipo de enfermeira

\author{
Fabíola de Araújo Leite Medeiros ${ }^{\mathrm{a}}$ \\ Jullyana Marion Medeiros Oliveira ${ }^{b}$ \\ Raquel Janyne de Limac \\ Maria Miriam Lima da Nóbrega ${ }^{d}$
}

\begin{abstract}
This article aimed to analyze the perception of the nursing team about the care of institutionalized elderly. It consists of a qualitative and exploratory study developed in the six long-term care nursing homes for elderly in the city of João Pessoa/PB, Brazil, from January to June 2013. The sample was comprised 50\% of the nurses from all the institutions, totaling 13 participants, whose data were collected through semi-structured questionnaires. Content analysis was used in the study, which enabled the construction of two thematic categories: I) Perceptions of the delivery of care by the nursing staff of the institutions; II) Perceptions of the care activity to be performed by the nursing staff in the institutions. We conclude that the participants are aware of the need for an individualized and systematized care by the nursing staff, aimed to the prevention of diseases, health promotion and active aging.
\end{abstract}

Keywords: Nursing Homes for the aged. Aging. Nursing care.

\section{RESUMO}

Objetivou analisar a percepção da equipe de enfermagem sobre o cuidar de pessoas idosas institucionalizadas. Estudo qualitativo e exploratório, realizado nas seis instituições de Longa do município de João Pessoa (PB), Brasil, entre os meses de janeiro e junho de 2013. Participou 50\% do universo de funcionários de enfermagem das instituições, totalizando 13 participantes, cujos dados foram coletados por meio de um questionário semiestruturado. Utilizou-se a análise do conteúdo, e foram construídas duas categorias temáticas: I) Percepções sobre a realização de cuidados pela equipe de enfermagem nas instituiç̧ões; e II) Percepções sobre o ato de cuidar a ser desenvolvido pela equipe de enfermagem nas instituições. Conclui-se que há uma compreensão da necessidade de um cuidar individualizado e sistematizado pela equipe de enfermagem, que vise à prevenção dos agravos, à promoção da saúde e ao envelhecimento ativo nas instituições.

Palavras-chave: Enfermagem. Instituição de longa permanência para idosos. Envelhecimento. Cuidados de enfermagem.

\section{RESUMEN}

El objetivo fue analizar la percepción de los profesionales de enfermería en el proceso de atención a la persona mayor institucionalizada. Estudio cualitativo y exploratorio que se utilizó de un cuestionario semiestructurado. La muestra consistió en un 50\% de la población del personal de enfermería de las seis instituciones visitadas, con 13 participantes que integran el personal de enfermería de seis hogares para ancianos en la ciudad de João Pessoa/PB, Brasil. Los datos se estructuran en dos categorías de respuesta: I) Percepciones sobre el logro de la atención por parte del personal de enfermería en los hogares para acianos, II) Percepciones sobre el acto de cuidar a desarrollar por el personal de enfermaría en los hogares para ancianos. El proceso de atención en los hogares para ancianos por parte del personal de enfermería todavía se basan en el modelo biomédico. Pero está claro que hay una comprensión del personal de enfermaría de la necesidad de una atención individualizada y sistemática, dirigida a la prevención de enfermedades, promoción de la salud y envejecimiento activo.

Palabras clave: Enfermería. Hogares para ancianos. Envejecimiento. Atención de enfermería.
DOl: $\quad$ http://dx.doi.org/10.1590/19831447.2015.01.45636 


\section{口INTRODUCTION}

The increase in the elderly population and life expectancy in Brazil has generated significant social gains with great impact on human development. However, these benefits must be associated with a higher quality of life of Brazilian elderly. The care provided in this context will require the implementation of public policies that guarantee the rights of the elderly, the promotion of social inclusion activities by the management and the production of knowledge in teaching and research centers ${ }^{(1)}$.

The changes in the age and epidemiological profile in Brazil have been a main concern of scholars and managers in the field of gerontology, who, in their search for viable ways to improve the quality of life of older people, reflect on the vulnerabilities of the process of delivery of care for this population ${ }^{(2)}$.

Among the support networks, it is worth mentioning the Long Stay Institutions (LSIs) where many elderly choose to live or which provide shelter for elderly deprived of caregivers and/or in precarious conditions ${ }^{(3-5)}$.

One study shows that Brazilian LSIs, in general, need to hire additional staff for their multidisciplinary teams, such as: doctors, nurses, physiotherapists, speech therapists, nutritionists, physical education teachers, social workers and nurse assistants. Among these, the nursing staff plays a key role because it is directly involved in the care process ${ }^{(3)}$.

Nurses have the responsibility to perform administrative, care, educational and research functions. Therefore, we emphasize here the importance of the use of the nursing process as an essential tool for all nursing professionals in their institutions ${ }^{(3-5)}$.

The nursing process implemented in the institutions allows the organization of care by reducing the risk posed by the physical dependence of elderly, by tackling the determinants of health through continuous assessment of the functional capacity and by setting goals to be achieved with regard to meeting the needs of elderly, on an individual basis ${ }^{(3-5)}$.

The use of long-term care facilities as dwelling for elderly should be considered as a positive response to this population. Some studies report that in the absence of care planning, institutionalization can be considered a process associated to loss in the quality of life of elderly ${ }^{(3-5)}$.

More often than not, the nursing process in these settings has been characterized by caring for people as a compassionate attitude for those in need, without proper organization and planning. This has probably undermined the development of whole and quality care to be provided to humans in these institutions.
The importance of this study consists in drawing attention to the nursing process in LSIs, in order to provide insights for the future restructuring of nursing care practices in the institutions and, thus obtain improvement in the care to institutionalized elderly.

The study was based on the following guiding question: what are the perceptions of the nursing staff regarding the care to elderly people in LSIs? And, therefore, the main objective was to analyze the perceptions of the nursing staff on care provided to elderly in LSIs.

\section{METHODOLOGY}

This was an exploratory and qualitative research conducted in six LSIs in the city of João Pessoa/PB, Brazil, from January to June 2013. All the LSIs of the city were visited, according to data provided by the Regional Council of Nursing (COREN/PB). It should be stressed that all the LSIs of João Pessoa/PB, Brazil, at the time of data collection, were humanitarian organizations that housed, on average, 20 to 100 elderly.

There were 26 professionals of the nursing team in the six assessed LSIs. Of these, 13 (50\%) participated in the sample: (05 nurses and 08 nurse assistants).

Inclusion criteria: belong to the nursing team of the LSIs, being part of the permanent nursing staff, willingness to participate in the study, not performing care activities at the time of the collection. Exclusion criteria: work as a caregiver for elderly, attend a nursing course, not be part of the permanent personnel of the LSI.

Data collection was performed using a semi-structured questionnaire, applied through individual interviews. The instrument contained questions on socioeconomic and labor aspects, nursing training, education and knowledge on the process of care of institutionalized elderly and the nursing process. The following questions were posed to guide the perception of the nursing team: How do you perceive the care process of nursing in the institution? What suggestions do you propose to improve care in nursing?

Data were analyzed and categorized using Bardin's content analysis.(6) The statements were subjected to thematic analysis and were classified base on a previous analysis. They were organized and systematized after careful reading of the responses from the questionnaires, based on systematic literature review. Categorization and quantification of the thematic units was based on the responses obtained.

Two thematic categories were identified in this study: I) Perceptions of the delivery of care by the nursing team in the assessed institutions; and II) Perceptions of the care activity 
to be performed by the nursing staff in the institutions. Both categories were proposed based on data from Brazilian studies concerning the existence of an unwritten, systematic process of care in the institutions, and professionals in nursing and in the fields of gerontology and geriatrics should be aware of this process. Also, some published articles suggested further studies on the organization of the care process in long-term care nursing homes for elderly as a viable means to improve care standards $(5,7-10)$.

The presentation of the results was organized into the two thematic categories, identified by codes pre-established by the researchers, which include letter " $E$ " and specific numbering for the cataloguing procedures. The anonymity of the research is assured by a set of ethical principles. Given the similarity of the responses, two statements were selected to elucidate the results obtained by the present study.

All ethics principles for research involving human participants were observed and the protocol was approved and recorded at CAEE under No 10895812.7.0000.5188, being submitted to the Research Ethics Committee of Universidade Federal da Paraíba. All participants signed a Free Informed Consent Form, in accordance with the guidelines that govern human subjects' research in Brazil.

\section{RESULTS AND DISCUSSIONS}

The nursing team of the six LSIs visited was entirely composed of women between the ages of 20-39. Regarding the Nursing categories: five were nurses and eight were nurse assistants. Of the 13 participants, six reported having received training in care for elderly or some training in gerontology.

Studies conducted in Brazilian LSIs in different regions of the country showed an organizational structure of nursing similar to the one in the city of João Pessoa /PB, in the Northeast Region of Brazil. Studies revealed that most institutions have nurse professionals, mostly women ${ }^{(3,7)}$.

The analyzed results indicated two thematic categories related the perception of the nursing team about their tasks and what they could do to improve their daily work, regarding the provision of care to elderly, and also about how care should be delivered by the team in the institution.

\section{Category I: Perceptions of the delivery of care by the nursing team in the assessed institutions}

The care activities performed by the nursing team were unanimously described as distinct activities: the activities performed by nurses and the activities developed by nurse assistants. Nurses are responsible for: nursing appoint- ments, performing more clinically complex care activities e.g. regarding dressings, assessment of functional capacity and coordinating drug distribution according to medical prescription, referral to medical appointments and health education activities. In turn, nursing assistants reported that they performed activities related to drug administration, dressing prevention of pressure ulcers and measurement of vital signs.

The above mentioned activities were mostly performed in mutual collaboration of all the nursing professionals, together with the caregivers for elderly, who helped in routine activities, such as: walking, changing positions and body care. In three of the LSIs visited, the existence of nursing care routines and nursing appointments was reported.

The above care practices are in accordance with the practice of nursing in Brazil, consistent with decree no 94.406/87 that regulates Law 7.984/86 on the Practice of Nursing in Brazil, and including provisions on the professional competencies of Nurses and Nursing Assistants (11).

The members of the nursing team perceived their care actions in the institutions, including their professional responsibilities and the importance of individualized care to institutionalized elderly. However, all participants unanimously reported that systematized and individualized care often faces institutional obstacles such as lack of qualified personnel to care for elderly, which prevents actions from being implemented as planned.

The delivery of health care services in the LSIs should first meet the individual needs of each resident, particularly those related to the ability to perform daily activities. Many disabilities result from chronic diseases that require specific care services to meet basic human needs such as bathing, dressing, eating, going to the toilet, among other needs correlated to services provided in the care process ${ }^{(7-8)}$.

The following statements concern the routine care in the institution and the difficulties perceived by the nursing team in the execution of care practices:

The main care provided by me is related to the health status of elderly, and I have the following responsibilities: refer patients to the doctor, make dressings, oversee the distribution of drug, because there are a lot of drugs and elderly patients. My functions are more related to the control of health problems. (E.4)

Nursing shortage makes it difficult to meet the rising demand for services. I try to adopt a more individualized approach regarding care, but it is not easy. I do my best here. There are 110 elderly residents, and approximately half of them have difficulty in performing an essential daily activ- 
ity. We have to check their blood pressure and be attentive to pressure ulcers. (E.6)

The participants of the study were emphatic in expressing their wish for training of the nursing team in the fields of gerontology and geriatrics. The urgent need to address nurse staffing issues in the institutions was also reported to improve the nursing care for institutionalized elderly. This is consistent with another study in LSIs from other countries that reported understaffing as a major concern regarding the care to elderly who are not able to independently perform their daily activities ${ }^{(8)}$.

The basic nursing care provided to institutionalized elderly should be appropriately managed to meet the several needs of these patients. Better care for the elderly and structural and functional reformulation of the organizations can make it possible for elderly residents to have comprehensive health care and enjoy a pleasant life in their community ${ }^{(3)}$.

The interviews conducted by the nursing team revealed the need for better planning of actions by health care professionals. Also, the planned care in three LSIs visited was based on "biologizing" models that perceive care as a medical/curative care established by the physician, rather than an independent care provided by the nursing team.

Moreover, these data are consistent with data from other studies on the institutionalization of elderly, which report that nursing care were provided to support illness recovery, mainly focused on biomedical actions, and not concerned with a more humanistic and holistic view ${ }^{(3-5,7-10)}$.

There is urgent need to encourage the mobilization of public policies to support long stay institutions, by publishing studies on their situation and by seeking ways to solve the structural and functional problems faced by them.

In Brazil, the LSIs need to be restructured as spaces for promoting wellbeing and care must be provided to the elderly that resort to them. The LSIS are still perceived as shelters for neglected elderly, and not recognized for their therapeutic and institutional aspects.

The care provided to elderly in LSIs in Brazil concerns hygiene, administration of drugs and food. It should also include leisure activities and concern with the well-being of elderly ${ }^{(10)}$.

Also, the care practices adopted in the LSIs are not very much concerned with active aging. Health professionals should be more focused on the promotion of health and quality of life ${ }^{(12)}$.

The participants reported their concern with effective technical and professional training programs and with understaffing. They also reported the need for a more human and affectionate care. Their statements also indicate that they are please to take care of elderly in the LSIs.

The following statements reveal the subjective viewpoints of nursing professionals regarding the technical care provided to institutionalized elderly:

I think my job is rewarding. It's good to offer care and affection to the elderly, for I know that someday I can find myself in a similar situation. (E.6) The most important things involved in the care process in LSIs include love, patience and responsibility for the elderly, because most were abandoned by their families and feel sad and depressed when they arrive in the institution. We need to be more involved with these processes in LSIs because old age will come for us too. (E.10)

Institutionalized elderly often cease to be independent, for they have to share their lives with strangers and are frequently forced to change their habits, schedules and activities to adapt to the routine of some LSIs. The nursing team should obtain interdisciplinary and multidimensional knowledge in the fields of gerontology and geriatrics to support the understanding of the complex process of care in $\mathrm{LSIS}^{(13)}$.

Due to the high rates of dependency among elderly in long stay institutions greater investments are needed in human resources to ensure interdisciplinary and multiprofessional attention to health promotion and prevention of functional impairment. Therefore, the population aging poses a challenge to society, requiring the implementation of social and health policies consistent with the current situation of the LSIs and with the promotion of a good quality of life for the residents ${ }^{(13-15)}$.

During the collection of data for this study, it was found that of the six LSIs visited, five of them had one nurse station where the residents' records were kept. The control of individual drugs distributed in day and night shifts and indicated by different colors was very accurate (blue color for day shift and red color for night shift), as is done in hospitals. Of the six LSIs, three had a nursing ward for more intensive care for bedridden elderly with severe health problems, indicating that the institutions met the biomedical standards established for healthcare institutions in Brazil.

\section{Perceptions of the care activity to be performed by the nursing staff in the institutions}

Regarding the participants' perception on the actions needed to improve the care provided by the nursing team in the LSIs, it was found that planning could significantly 
improve the standards of the care delivered. This was evident in the following speech:

I haven't yet managed to implement the systematization of nursing care (SAE) involving more planned, individualized care and using specific terminology. I wanted to do it, but had no time or support. However, I have been planning the execution of my tasks, and based on the records of some bedridden elderly, I have described the nursing actions according to two process steps: prescription and evolution of nursing services to elderly who need more direct assistance from the nursing team. Here the nursing team records all the events related to resident elderly and records and submit this to the doctor. We do what we can, but responsibly (E.8).

The need for implementing a nursing record that contemplates the Systematization of Nursing Care (SAE) focused on the health of elderly, meeting their daily needs and ensuring the maintenance and recovery of their health conditions was identified. The team also agreed on the importance of developing a systematized process of health care that improved the quality of life of the residents.

The nursing team unanimously reported that the community and the families of the institutionalized elderly should understand that the LSIs are specialized dwellings aimed to provide gerontology and geriatric services, according to the needs of the residents, and integrated to a continuous care system. It is not a shelter for abandoned elderly. Care should be holistic, involving also the promotion of active aging, and not merely focused on routine care activities and disease control ${ }^{(3,5)}$.

Institutional and social involvement and public policies focused on institutionalized elderly are essential.

We should be aware that the population aging has generated a demand for increasingly specialized services, e.g. long stay institutions ${ }^{(3)}$.

Nursing training should also include in their curricula knowledge related to the elderly and the human aging process, comprising the debate on spaces for the promotion of the care to elderly provided by nurses ${ }^{(3)}$.

The Systematization of Nursing Care (SAE) presupposes knowledge on nursing theories, understanding of the life stages and the theoretical constructs underlying the science of $\operatorname{care}^{(3)}$.

The introduction of a nursing process in LSIs, with the establishment of nursing appointments, would create the necessary conditions to discuss the reasons for the institutionalization, allowing access to residents' health history, current health problems and the medications taken, as well as to the identification of important parameters in the assessment of functional capacity. The diagnoses made by nurses will identify the main nursing actions; the planning of activities will include one action to support the priorities of a therapeutic process that will be constantly assessed ${ }^{(14-15)}$.

The following statement demonstrates the concern of the participant with the elucidation of a proposal aimed to promote the health of elderly:

This year I intend to reassess the functional capacity of all the residents, in order to obtain evaluating parameters of nursing behaviors that support active aging. (E.13)

This statement illustrates again the concern of the nursing team with the care process in nursing, facilitating more individualized health care approaches, going beyond the "biologizing" model. There is much to be done to (re) construct a more human, more dignified and why not say, more supportive nursing care, within the principles of scientific knowledge of the profession and the current professional practice in Brazil for the nursing staff.

\section{— FINAL CONSIDERATIONS}

This study allows to conclude that the nursing teams that worked in the LSIs perceived the essential nature of their functions: care to their clients and users of their services, in this case, institutionalized elderly.

The professionals perceived themselves as essential parts of routine care. They need more support regarding the organization of the nursing services, training in gerontological and geriatric nursing and increase in the nursing staff of the institutions.

The participants reported that the nursing team performed activities based on the individual needs of each elderly resident, under a perspective of the "biologizing" model. Also, they were found to be aware of the need for technical training to support nursing conduct in long stay institutions.

One limitation of the study was the reduced number of professionals of the nursing team in the assessed institutions, requiring them to perform too many tasks in their routines observed during data collection. Another limitation was the lack of institutional support to the demands of the nursing staff related to care planning.

It is concluded that it is essential to undertake further studies on nursing care in the LSIs in order to improve their actions to support the elderly residents. It is also important to demystify the LSIs as former shelters for abandoned elderly. And finally, it is necessary to promote the importance 
of these institutions as therapeutic environments, as spaces to promote dignity, privacy and wellbeing to all those who enjoy it: the elderly themselves, the employees and the community.

\section{REFERENCES}

1. Veras R. Envelhecimento populacional contemporâneo: demandas, desafios e inovações. Rev Saúde Pública. 2009;43(3):548-54.

2. Santos AA, Pavarani SCl. Perfil dos cuidadores de idosos com alterações cognitivas em diferentes contextos de vulnerabilidade social. Rev Gaúcha Enferm. 2010;31(1):115-22.

3. Silva BT, Santos SSC. Cuidados aos idosos institucionalizados: opiniões do sujeito coletivo enfermeiro para 2026. Acta Paul Enferm. 2010;23(6):775-81.

4. Jesus IS, Sena ELS, Meira EC, Gonçalves LHT, Alvarez AM. Cuidado sistematizado a idosos com afecção demencial residentes em instituição de longa permanência. Rev Gaúcha Enferm. 2010;31(2):285-92.

5. Marinho LM, Vieira MA, Costa SM, Andrade JMO. Grau de dependência de idosos residentes em instituições de longa permanência. Rev Gaúcha Enferm. 2013;34(1):104-110.

6. Bardin L. Análise de conteúdo. 4 ed. Lisboa: Geográfica Editora, 2009.

7. Jesus IS, Sena ELS, Meira EC, Gonçalves LHT, Alvarez AM. Cuidado sistematizado a idosos com afecção demencial residentes em instituição de longa permanência. Rev Gaúcha Enferm. 2010;31(2):285-92.
8. Onder G, Carpenter I, Finne-Soveri H, Gindin J, Frijters D, Henrard JC et al.; SHELTER Project. Assessment of nursing home residentes in Europe: the services and health for elderly in long term care (SHELTER) study. BMC Health Services Research. 2012;12(5):1-10

9. Oliveira DN, Gorreis TF, Creutzberg M, Santos BRL. Diagnósticos de enfermagem em idosos de instituição de longa permanência. Ciênc Saúde Coletiva. 2008; 1(2):57-63

10. Creutzberg M, Gonçalves LHT, Santos BL, Santos SSC, Pelzer MT, Portella MR, et al. Acoplamento estrutural das instituições de longa permanência para idosos com sistemas societais do entorno. Rev Gaúcha Enferm. 2011;32(2):219-25.

11. Presidência da República (BR). Lei nº 7498 de 25 de junho de 1986. Dispõe sobre a regulamentação do exercício da enfermagem, e dá outras providências. Diário Oficial da União [da] República Federativa do Brasil. 1986 jun 26;124(119 Seção 1):9273-9275.

12. Freitas AVS, Noronha CV. Idosos em instituições de longa permanência: falando de cuidado. Interface Comunic Saude Educ. 2010;14(33):359-69.

13. Rissardo LK, Furlan MCR, Grandizolli G, Marcon SS, Carreira L. Sentimentos de residir em uma instituição de longa permanência: percepção de idosos asilados. Rev Enferm UERJ. 2012;20(3):380-5.

14. Marinho LM, Vieira MA, Costa SM, Andrade JMO. Grau de dependência de idosos residentes em instituições de longa permanência. Rev Gaúcha Enferm. 2013;34(1):104-10

15. Santos SSC, Valcarenghi RV, Barlem ELD, Silva BT, Hammerschmidt KSA, Silva ME. Elaboração de prontuário do residente em uma instituição de longa permanência para idosos. Acta Paul Enferm. 2010;23(6):725-31.
Author's address:

Fabíola de Araújo Leite Medeiros

Rua Baraúnas, 351, Bairro Universitário

58429-500, Campina Grande, PB

E-mail:profabiola@bol.com.br
Received: 14.03.2014

Approved: 03.03.2015 